\title{
Shareholding Interest in Companies Listed on B3 in 2018: A Study of Networks
}

\author{
Caroline Alvarenga Carvalho ${ }^{1, *}$ \\ ${ }^{1}$ Universidade de São Paulo, Ribeirão Preto, SP, Brazil \\ Evandro Marcos Saidel Ribeiro ${ }^{1, \dagger}$ \\ ${ }^{1}$ Universidade de São Paulo, Ribeirão Preto, SP, Brazil
}

\begin{abstract}
The shareholding structure of large companies interferes with market competition, as well as the financial stability thereof. Some international studies have analyzed the control network of companies in their corresponding countries, others have broadened such vision to transnational companies, conducting a world level analysis, with both aiming to describe the willingness of the main shareholders regarding the network structure. Thus, the challenge herein is to elaborate and analyze the network of shareholding in companies listed on B3 in 2018. This paper will be descriptive research that uses Network Analysis of data obtained from Economatica software. As a result, we find a network with a giant component comprised of 726 players and a shareholders' network of low density, high modularity and with main players of high influence. The results contribute to understanding the current structure of the Brazilian stock market share and are expected to encourage new researcheson the Brazilian financial market.
\end{abstract}

\section{KEYWORDS}

Shareholding interest, Network theory, Complex systems

CORRESPONDING AUTHOR

*Caroline Alvarenga Carvalho

E-mail: carolinealvcarvalho@gmail.com

${ }^{\dagger}$ Evandro Marcos Saidel Ribeiro

E-mail: esaidel@usp.br

Received: 02/06/2018.

Revised: 26/09/2018.

Accepted: 18/12/2018.

Published Online: $21 / 08 / 2019$

DOI: http://dx.doi.org/10.15728/bbr.2019.16.5.6 


\section{INTRODUCTION}

The study of networks has an interdisciplinary approach and is gaining prominence in the field of applied social sciences, especially in the Business Administration field, which has much content to be explored by network analysis (Ribeiro, 2014). In short, a network consists of a set of discrete elements, called vertices (or nodes), and a set of edges that connect the vertices (Newman, 2010) and can be applied in several situations to describe how the players (nodes) relate to one another. The relevance of network techniques lays on enabling a complex analysis of the interactions between the players studied. Using this technique, it is possible to see beyond the primary level of connections between the players, to analyze the role of each player in the dynamics of the network, and to visualize what is underpinning the interactive flows, proceeding with a wide-ranging analysis regarding the interactions phenomenon.

Relating the study of networks to Business Administration area, Vitali, Glattfelder, and Battiston (2011) conducted a research on international corporate property networks using the calculation of potential control of each player in the market. As a result, they observed that transnational corporations make up a network with a structure known as bow tie, where much of the control comes from the periphery in to a small, tightly united core consisting of large financial institutions. According to the authors, this core can be understood as important economic agents, raising significant questions both for researchers and policy makers, due to the power of interference in the market, determining a level of risk for the economy.

Thus, motivated by the approach by Vitali, Glattfelder, and Battiston (2011), this research aims to elaborate and analyze the network formed by shareholders and publicly traded companies listed in B3 in 2018. To this end, the network of companies and shareholders was prepared through the Gephi software and B3 data obtained through Economatica, so that it could be analyzed according to its structure and position measures of its players, thus raising statistics that allow to indicate key players and the constitution of groups.

The resulting network is composed of 1,742 nodes in which it is possible to see a giant component formed by approximately $41.7 \%$ of these nodes, with highly connected hubs and the three central shareholders: BNDESPar, Previ and BlackRock. From the giant component, there was obtained a network with 573 nodes, characterized by low density, high modularity and medium path indicating characteristics of the small world network. In highlight, players of the financial sector, holdings, private equity companies, and funds are organized throughout the network acting as important connectors, while natural persons are mainly at the extremes, not acting as important intermediaries.

Thus, the main contribution of this paper is presenting the network of shareholding in the Brazilian stock market share. It was possible to observe that the BNDESPar, Previ and BlackRock shareholder groups occupy a central position with high influence on the network and BNDESPar, a state holding company, and the most central actor among the three, indicating an important performance of the government as a shareholder in the stock market. The subject is relevant because it studies the ownership structure of important companies in Brazil, applying a widely used technique of network analysis, collaborating with the advancement of research in Business Administration in relation to the study of shareholdings and to the use of network theory. 


\section{THEORETICAL REFERENCE}

The content of this paper is presenting three main topics. The first addresses shares, ownership and control, the second addresses the main features of network theory, and the third one consists of a brief summary of Vitali, Glattfelder, and Battiston (2011) paper, the basis for this research.

Regarding shares and ownership, shares consist of securities issued by corporations and represent the smallest part of the share capital of the issuing company, being convertible into cash through stock exchange or over-the-counter. Investors in the Capital Markets are those lending their money to companies by purchasing securities, which characterizes an alternative investment in the face of traditional investments offered by banks and the government, while from the companies perspective, the issue of securities is a form of raising funds (CVM, 2013).

There are two types of shares: common and preferred shares. Common shares are those that grant ownership powers to shareholders, who have the right to vote in general meetings, that is, the possibility of interfering in important decisions. Preferable shares do not grant voting rights, but the shareholders have priority in the receipt of dividends, repayment of capital or other terms defined in the Bylaws of the organization (Fortuna, 2008). Those who invest in shares are co-owners of the corporation where they hold shareholding interest, having all duties and rights of a partner proportionally to the shares they hold. The buying and selling of shares can result in different forms of ownership and hence different management challenges, as explained by the Agency Theory.

Due to the various changes within the economic and social context, organizations undergo changes in order to adapt to the context in which they are inserted, changing their position and organizational structure. An example is the emergence of large corporations and the existence of a new model of business control characterized by the total or partial decentralization of the ownership. After such changes, many companies that used to be managed by their owners are now managed by other officers, therefore separating ownership and management. In this new model, the owner of the company, the so called "principal", delegates decision-making power to the officer, or "agent", according to Agency Theory (Jensen \& Meckling, 1976).

Agency Theory considers the conflicts and costs resulting from a certain capital structure, such as the separation between ownership and control, for example. The agency relationship is defined by Jensen and Meckling (1976) as a contract through which one or more people (the principal) employs a second person (the agent) to carry out, on the principal's behalf, work consisting of the delegation to the agent of some decision power. However, the authors state that both the principal and the agent tend to maximize their own wealth and may act according to different interests. This misalignment between the two parties gives raise to the agency issues. The possibility that the shareholder may not take part in the management of a company is well represented in corporations, once the responsibility of the shareholder towards the organization is limited according to the capital share invested (Segatto-Mendes, 2001).

The separation between ownership and control occurs when those holding the shares do not have control over the company (Leal, Silva, \& Valadares, 2002). That gives rise to an agency issue called principal-agent, when faced with the probability that managers will place their own interests over the objectives of the companies or the owners thereof, according with Gitman (2010). Gitman (2010) illustrates this conflict by stating that, although the chief financial officer of a company agrees with the objective of maximizing the wealth of shareholders, he is also concerned with the stability and security of his benefits and his employment, which can result in lower returns, considering that the chief financial officer may avoid taking some risks that may jeopardize the stability of his job. Another possibility of agency conflict, called principal- 
principal, normally occurs when there are controlling and minority shareholders in the same company, as the controlling shareholders have decision power over the administrators (agents) and act according to their own interests. Therefore, there are mismatched ideas and, consequently, conflicts occur among the principals.

Regarding the ownership structure, Silveira (2015) states that it consists of the way in which the shares are distributed among the partners. Jensen and Meckling (1976) state that such structure is determined by the ratio of the amount of resources allocated by internal and external shareholders and that not only relative amounts of debt and equity should be considered, but also the fraction of the shareholders' equity manager, and this structure can be shaped according to the environment in which the organizations are inserted, such as a political regime, legislation, capital market structure, and the history of industrialization and culture (La Porta, Silanes, \& Shleifer, 1999; Siffert Filho, 1998). In Brazil, the ownership structure is characterized by the concentration of the corporate structure culminating, in general, in the overlapping of ownership and management of companies, according to Caixe and Krauter (2013).

Such a property structure determines the type of existing agency conflict. In the event of a structure with diffuse actions, the conflict of interests occurs between the principal (shareholders) and the agent (administrator), as presented by Berle and Means (1932). However, in the case of ownership structures focused on a controlling shareholder that has the power to control the decisions of the administrator, the conflict of interest occurs between principal-principal, that is, between controlling and minority shareholders (Claessens, Djankov, Fan, \& Lang, 2002).

In regards to the Brazilian capital market, companies traditionally have a concentrated ownership structure, that is, there is a concentration of voting capital held by a small number of shareholders. This characteristic lead to the agency conflict between controlling and minority shareholders, as previously stated, where each of the players tend to maximize their usefulness (Araujo \& Santos, 2016).

In finance, the term control is widely used by scholars as the ability of a shareholder to influence strategic decisions in a company. Vitali, Glattfelder, and Battiston (2011) refer to the term control as the economic value of companies that an investor is able to influence. Conducted in 2011, "The Global Corporate Control Network" is the study used as the basis for the research that gave rise to this article, and whose main objective was to develop the network of business controllers worldwide, being the first investigation of internationally owned network architecture, together with the measurement of the control of each player. Network analysis was used due to the existence of a web of direct and indirect properties that extends across several countries, and to the fact that pyramids are formed by subsidiary companies. As a result, the players found that shareholders with a high level of control are those potentially capable of imposing their decision on many high-value companies. Thus, the higher the control of a shareholder, the bigger their power to influence the final decision.

Grounded in the theory of graphs and sociology, network science is a relatively new field, which has gained prominence in the 21 st century. One of the main characteristics is its interdisciplinary nature, impacting many areas such as health, economy, safety, neuroscience, management, among others (Barabási, 2016).

The use of network techniques is a way to understand complex systems, analyzing how their components interact with each other. The network is, in simple terms, a bundle of points united by lines, where these points are referred to as vertices or nodes and the lines are referred to as edges or bonds (Newman, 2010). Figure 1 shows a network representation, with a simple language able to study many systems, which may be different in nature or scope. 
Another way of representing a network consists of a matrix where each cell element shows how a player relates to another (line vs. column). The simplest mathematical to codify such information, using an adjacency matrix with binary classification: if there is relation the value equals one (1), if there is not relation the value equals zero (0).

The main types of existing networks are: directed, bipartite and weighted networks. Directed networks are different from the others because of the need to identify not only the existence of a bond between the two players, but also whether these are caused by player A to player B, or by player B to player A. In this type of network, therefore, an edge shall be directed to a node with an arrow indicating the direction of the existing bond.

Another type of network is the bipartite, where the nodes can be divided into two different categories, so that each existing connection links a node from one category to a node of another category (Barabási, 2016). For example, Ribeiro (2014) prepared a network formed by companies (nodes $\mathrm{X}, \mathrm{Y}$ and Z) and directors (nodes A, B, C and D) that take part in the business council, according to Figure 2.

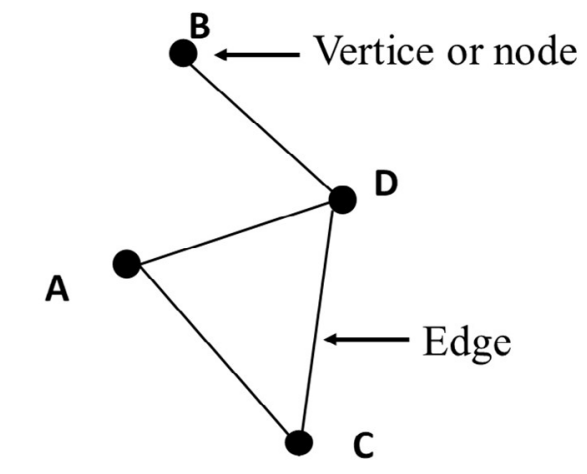

Figure 1. Network representation.

Source: prepared by the authors (2018).

(a)

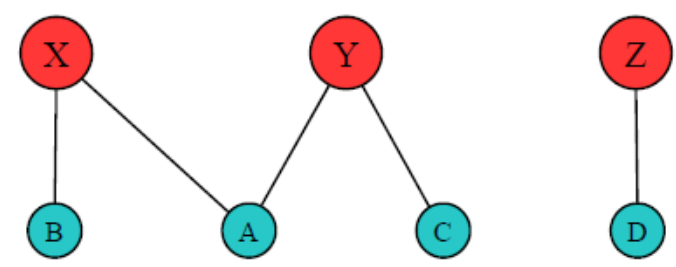

(b)

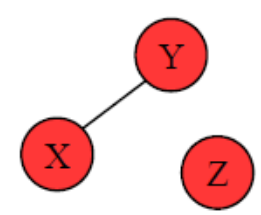

(c)

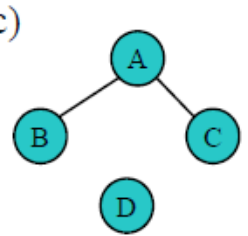

Figure 2. Bipartite networks. Companies (nodes X, Y and Z) and directors (nodes A, B, C and D). (a) Bipartite Projection Company-Director; (b) Projection Company-Company; (c) Projection Director-Director.

Source: Ribeiro (2014, p. 44). 
Item (a) of Figure 2 shows a network formed by companies and directors, that is, a bipartite network with two categories of nodes. Item (b) shows the simple network, formed only by companies, where the connection between $\mathrm{X}$ and $\mathrm{Y}$ takes place through node $\mathrm{A}$, which is hidden being only represented by the edge. Item (c) shows another simple network, but formed only by directors, where the connection between $\mathrm{A}$ and $\mathrm{B}$ takes place through node $\mathrm{X}$, and the connection between $\mathrm{A}$ and $\mathrm{C}$ takes place through node $\mathrm{Y}$.

Regarding the weighted networks, these are used when the connections between nodes have different degrees of intensity, which means it is important to differentiate the weight of connections. In simple networks, adjacency matrices are formed by the numbers zero and one, indicating the absence or the presence of connections between the nodes, while in weighted networks the numbers indicates the intensity of connection between nodes (Newman, 2010; Barabási, 2016).

Baran (1964) presents a classification for networks according to the arrangement of their nodes and edges, which is divided in three types: centralized, decentralized and distributed networks. Centralized networks are those where a main and central node connects the several nodes in the network. In distributed networks, the nodes have several connections, but without a central player responsible for connecting the part to the others. Finally, the decentralized network is in between these two types presented above, which has several central nodes that are responsible for the connection of the entire network. Figure 3 shows centralized, decentralized and distributed networks, respectively.

There are five main network metrics related to nodes, namely: degree, proximity, intermediation, PageRank, and paths and distances. These items form a quantitative basis that is essential for studying the networks. The degree of a node represents the number of edges connected thereto. This metric can be used to answer questions like: Which one is the most important node? Which one is the most central node in the network? Therefore, the degree of a node is considered to be a central measurement in the network: the higher the node degree, the higher the number
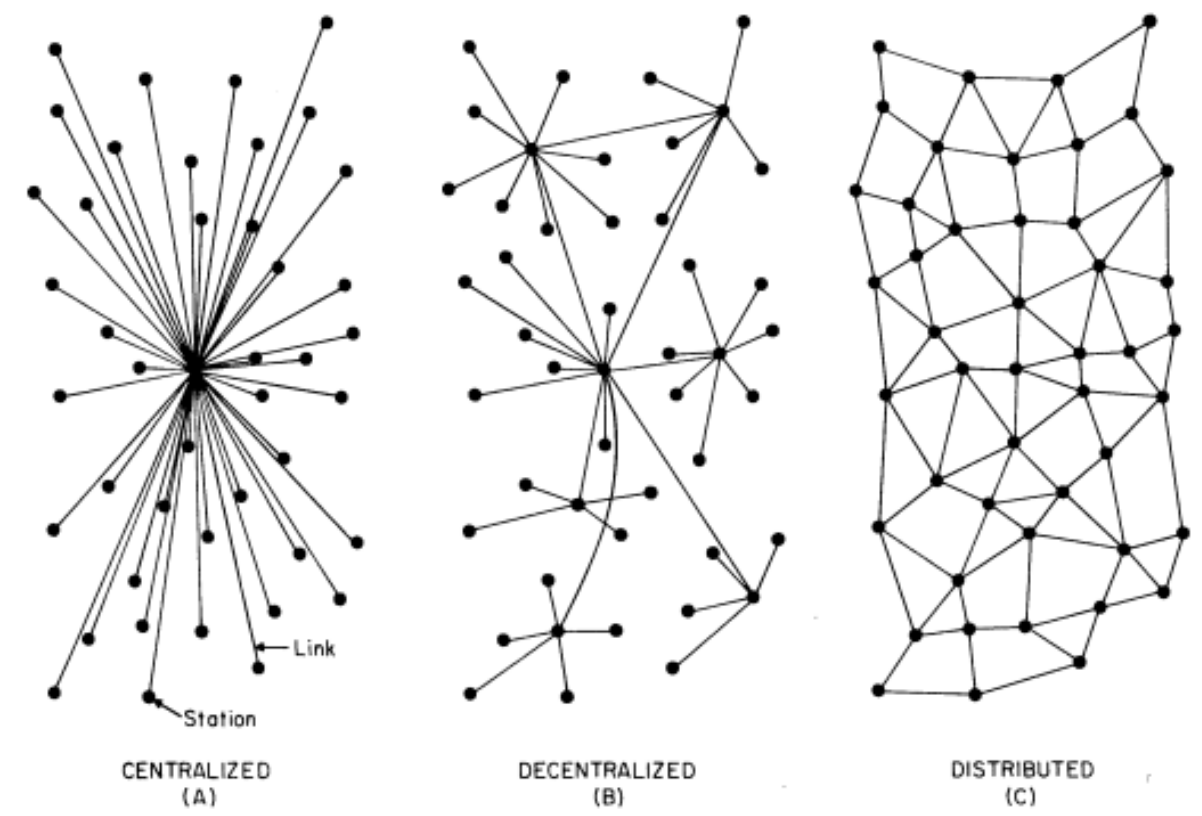

Figure 3. Centralized, decentralized and distributed networks.

Source: Baran (1964). 
of connections and the better its centrality in the network, in line with Newman (2010) and Scott (2017).

Proximity is a measurement offered by the proximity centrality, measuring the average distance of a node to the other nodes. Usually, the inverse of distance is defined as a measure of centrality, and proximity is the mean of the inverse of the distances between all nodes (Newman, 2010). The intermediation measures the extension of how much a node is in the path between other nodes. Assuming a network to be something that flows among the nodes through the edges as, for example, political information flowing in a network of people to people, the simplest assumption is that each pair of nodes exchange messages with the same probability per unit of time, with the message always flowing through the shortest path (geodetic paths). Thus, the intermediation measures the intensity through which a node is present in paths, considering that nodes with high intermediation have a significant influence on the network, as they may have control over the information sent to other nodes (Newman, 2010).

PageRank consists of a centrality measure that takes into account the type of each connection. The value thereof is a probability and reflects the chance a node is accessed in a network. This measure is obtained by algorithms that may be verified in Newman (2010). This measure is part of Google's webpage rating technology and aims to generate lists of webpages based on the search text, classifying them according to the relevance (Newman, 2010).

In a network, path refers to any sequence of nodes connected by edges; it is a route that goes through the connections of a network, and the length of the path is represented by the number of connection existing therein (Barabási, 2016). In a directed network, the paths can be defined according to the direction indicated by the arrow, while in a non-directed network the track can follow both directions (Newman, 2010).

Global network measures involve numbers that represent the general properties of a network. The measurements considered relevant for this study are average degree, density, number of components, diameter and average path length.

Average degree, which is the simplest of the global measures, is obtained by the mean of the degree of all nodes, evidencing the amount of average links between nodes. The density measures how connected are the nodes of a network. The more connected, the denser the network is. The maximum number of bonds that can be established between the nodes is given by $\mathrm{N}(\mathrm{N}-1) / 2$, where $\mathrm{N}$ is the number of nodes in the network (Lazzarini, 2008). Number of components indicates the number of groups in the network, that is, the group of nodes that are connected by one or more paths in a network. Finally, the diameter indicates a higher geodesic distance existing between a pair of nodes in the network, while the average path length shows the mean of the geodesic paths between all pairs of nodes of the network (Barabási, 2016; Easley \& Kleinberg, 2010). Networks with very connected nodes have smaller average path length and diameter, showing closer proximity and a more cohesive network.

Several networks are naturally divided in groups or communities. Barabási (2016) state that in network science, groups of nodes that are most likely to connect to each other are called communities, and a community consists of a sub graph densely connected in a network. Figure 4 presents an example of a network with three communities.

In order to enhance the detection of communities, the modularity measure is widely used in many algorithms. Modularity can show how intense the group division is within a network, with its value ranging from 0 to 1 , where 0 indicates total randomness of the network and 1 indicates communities clearly visible on the network (Carneiro, 2017). The algorithm used for the present research was created by Blondel, Guillaume, Lambiotte, and Lefebvre (2008). 


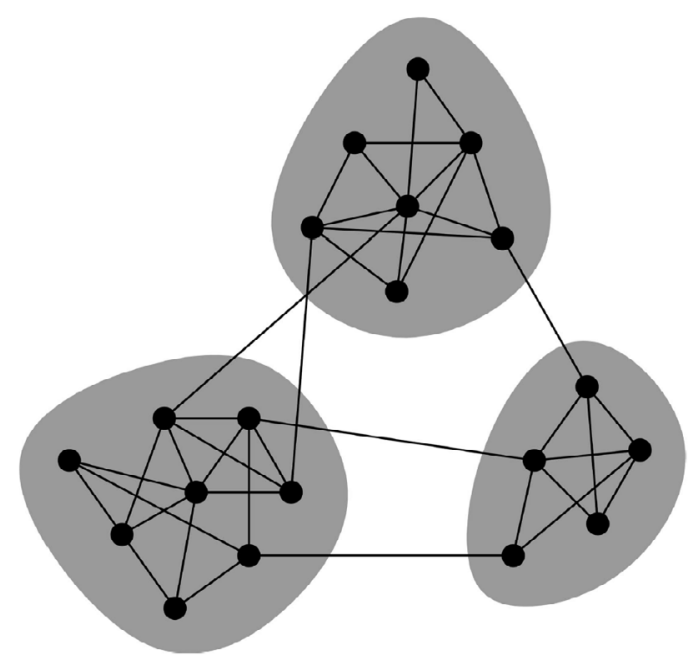

Figure 4. Network Communities.

Source: Newman (2006, p. 8577).

\section{METHODOLOGICAL PROCEDURES}

Data used in this work refers to publicly traded Brazilian companies with shares traded on B3. It is important to highlight that the preparation of the database originated from the universe of companies listed on B3, as it contains a significant number of the main companies operating in Brazil. Data was obtained through Economatica software, in survey conducted on Feb. 21, 2018 searching for most recent information available. In section "Matrix" of Economatica software, all companies listed on $\mathrm{B} 3$ were selected, thus obtaining a list with the names of companies the codes and the class of traded shares. The names of the ten largest shareholders, as well as their relevant percentage shares and the total asset value of each company were selected from this list. This survey resulted in a list formed by 566 lines, that is, 566 types of shares traded on B3.

The information regarding the common shares was selected from this list, since it is the type of action that allows its holders to vote in the cases discussed in General Meetings, that is, it confers the power to influence strategic organizational decisions (in this approach agreements between shareholders were not considered). Thereafter, a list with 368 companies that hold common shares traded on B3, their largest shareholders and their relevant percentage shares was obtained. The last cut out was the exclusion of a company whose information on percentages and names of shareholders were not released.

After processing the database, spreadsheets with the node and edges were created for the network, according to the necessary requirements to insert them in Gephi, a software specific for network analysis. The node spreadsheet features the names of the companies and the shareholders included in the database, as well as the category description (if a node is a shareholder or a company). The edge spreadsheet contains the direction of the connection (from shareholder to company), as well as the weight of each one of them, given by the percentage share multiplied by the total asset value (for these values, logarithmic scale was used).

The techniques of data analysis used were descriptive statistics, graphical analysis and network visualization technique for the descriptive aspect of the network. Techniques were applied using Gephi, a open-source software widely used for exploration and visualization of graphs and networks (Gephi, 2017). In regards to descriptive statistics, this is very useful for creating summaries on the network players, according to the metrics obtained in the software, besides 
preparing graphics and allowing to make comparisons between different groups. The graphical analysis was also performed by Gephi software, which is a platform for interactive exploration and visualization for different types of networks and complex systems, which instantly provide several network statistics.

\section{RESULTS}

\subsection{Network of Shareholders and Companies}

The resulting network is composed of 1,742 nodes (where 367 are companies, 1,375 are shareholders) and 1,662 edges. This obtained network was treated using Gephi software, resulting in a bipartite network layout, according to Figure 5. The blue nodes represent the companies, the red nodes represent the shareholders, and the edges represents the existence of shareholding interest in a certain company by a certain shareholder. The size of the nodes was scaled according to its degree; consequently, the larger nodes are those that have the largest number of edges, that is, more links in the network.

The network obtained presents 175 components, that is, 175 groups of connected nodes. Figure 6 shows the number of nodes present in each component, as well as the giant highlighted component, with 726 nodes; about $41.7 \%$ of the total nodes of the network. It is also observed that about $93 \%$ of the components in the network have a size between 2 and 11 , while the rest is divided between sizes 13 and 22, except for the giant component, with size 726 .

Table 1 presents a summary with the main information and measures regarding the centrality of the network studied hereunder.

Figure 5 and Figure 6 show that there are countless small components that are mostly centralized at the nodes of the company, that is, a single company with several shareholders that are not elsewhere interconnected with each other, but only by that company. Therefore, in a macro view, a little dense network is observed, which contains several small, centralized components and a giant decentralized component, evidencing companies and shareholders that form several small peripheral groups disconnected from a large central group. It is important to highlight three central shareholders in the network, namely: BNDESPar, Previ and BlackRock.

\subsection{Giant Component}

The network shown in Figure 5 was filtered in order to obtain the giant component, which consists of the largest number of nodes connected to each other in the network, containing 798 edges and 726 nodes, about $41.7 \%$ of the nodes of the macro network. The distribution of degree of the giant component, as shown in Figure 7, ranges from 01 to 31, where 1 is the most frequent degree. The nodes with degrees 14, 17 and 31 should be highlighted, as these are the three most connected players of the giant component: BlackRock, Previ and BNDESPAR, respectively. In summary, Figure 7 shows a joint view of the distribution of macro network degree with all players (circles) and the giant component (squares). The reduction of the frequency of nodes with smaller degrees in the giant component, as well as the presence of hubs with high degrees, is observed.

Taking into account other centrality measures calculated for the giant component, such as PageRank, intermediation and proximity, the shareholders BNDESPar, Previ and BlackRock are also highlighted, thus confirming their roles as central players in the network. Table 2 presents such measures for the 10 nodes with the highest PageRank. 
BBR

16

528

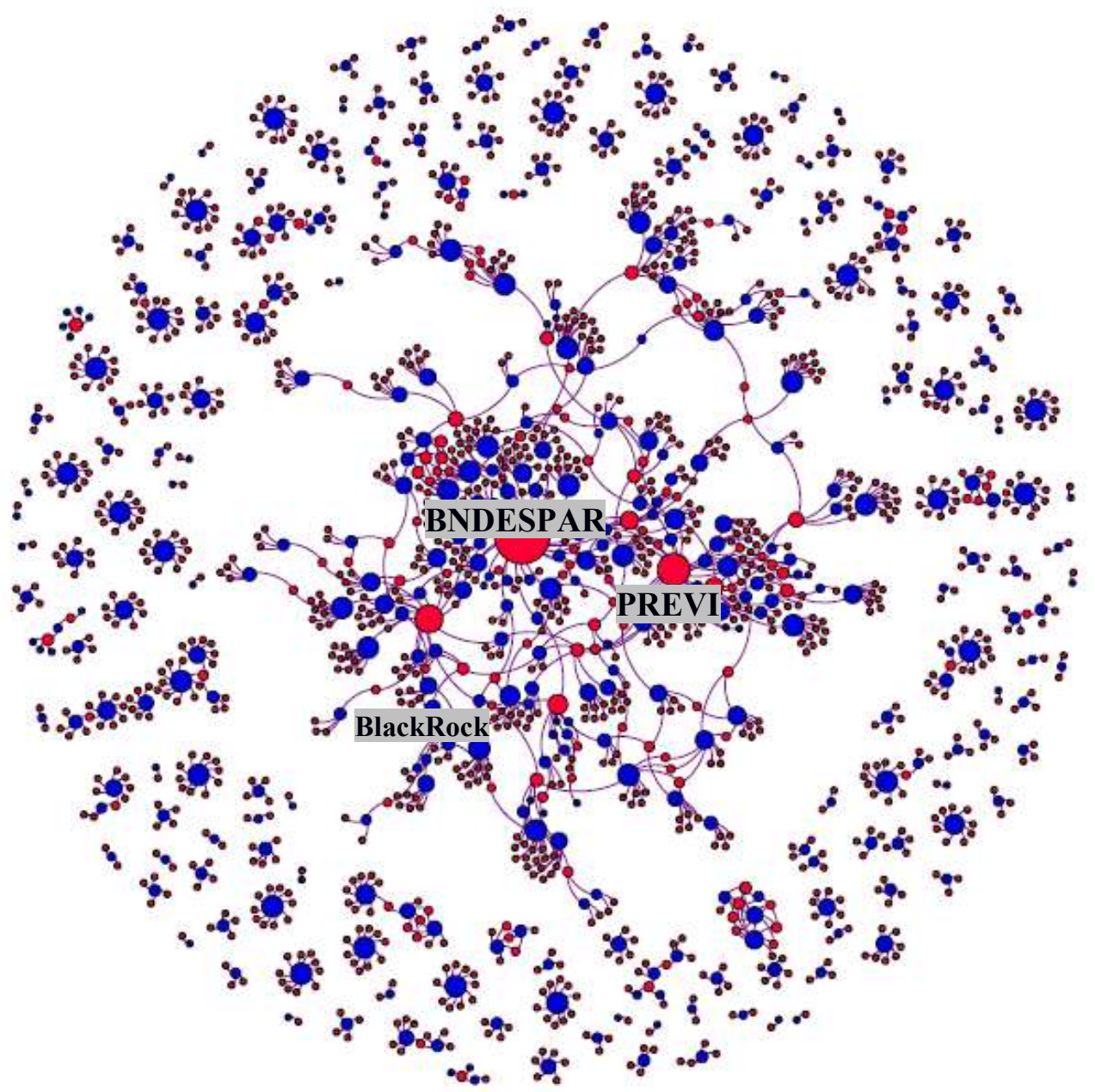

Figure 5. Bipartite network with 1,742 nodes (shareholders and companies). Blue: company; red: shareholder. Source: Prepared by the authors, obtained using Gephi (2018).

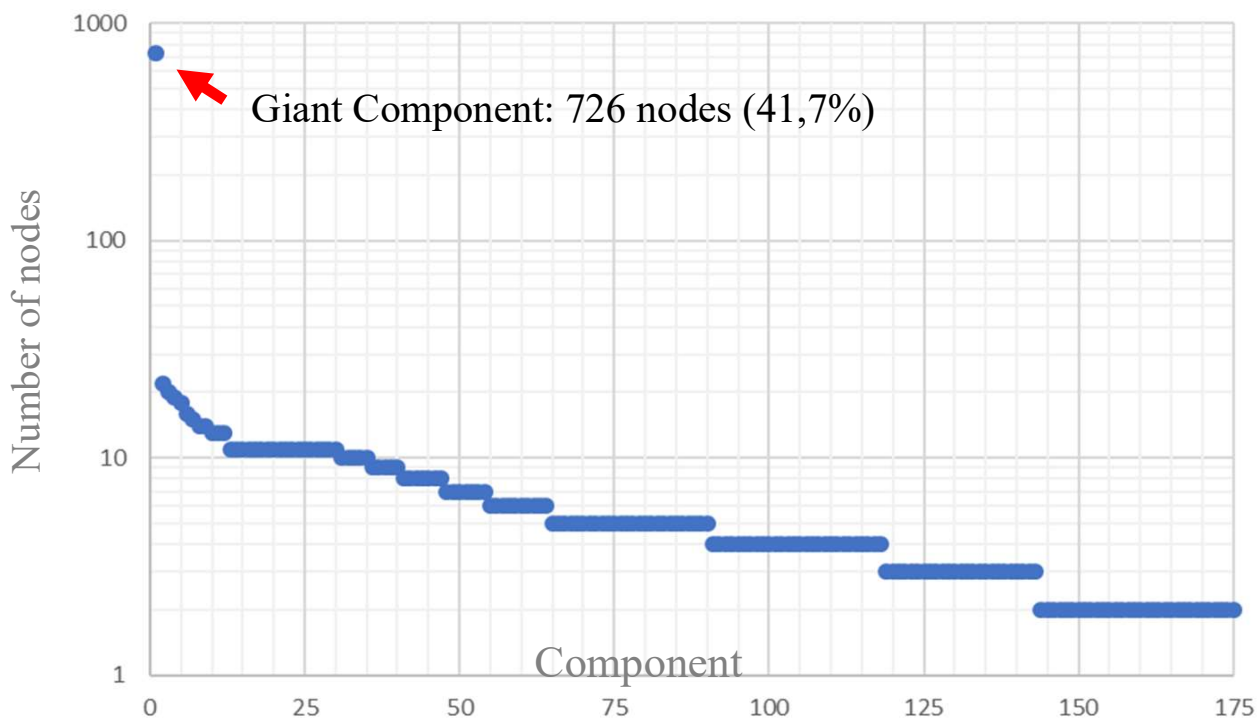

Figure 6. Size of components.

Source: Prepared by the authors (2018). 
Table 1

Macro Network Information

Network

Shareholders and companies

Type

Not directed

Number of nodes

1,742

Number of edges

1,662

Average degree

1.908

Connected components

$\%$ of nodes in the giant component

$41.68 \%$

Diameter

20

Density

0.001

Average path length

7.587

Source: Prepared by the authors (2018).

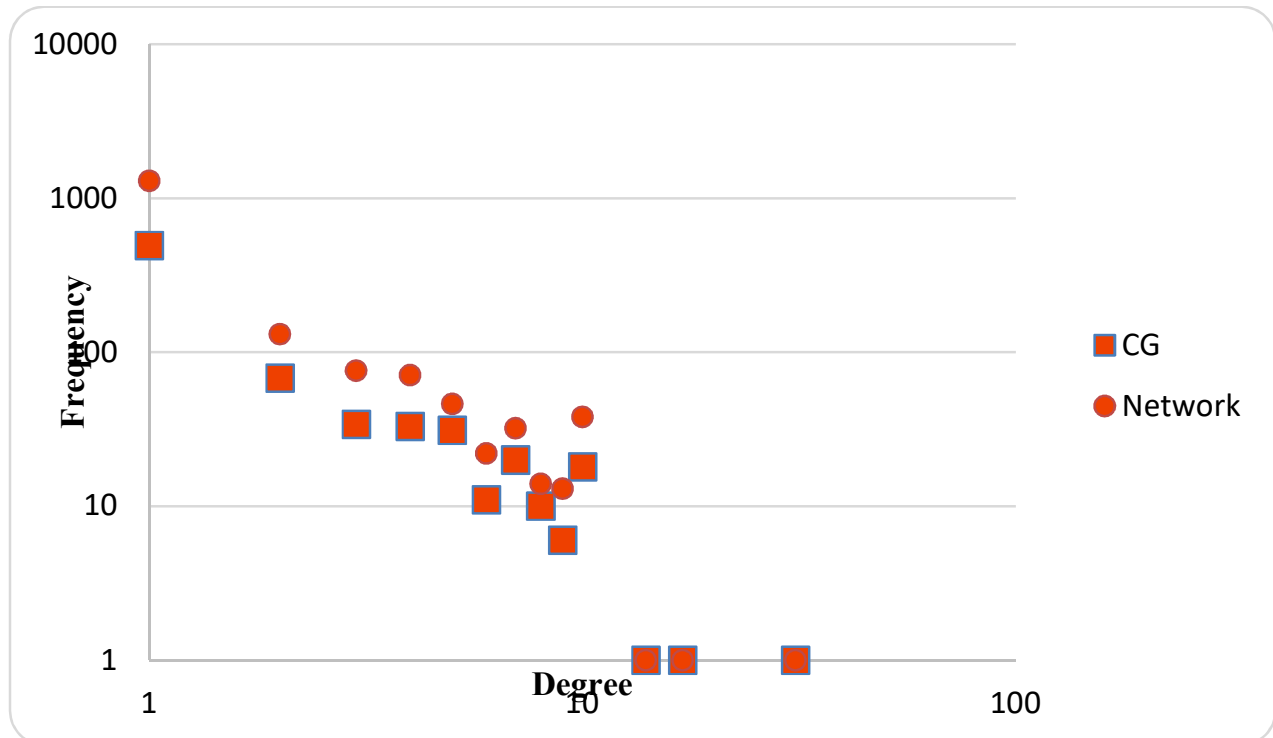

Figure 7. Distribution of degree of the components.

Source: Prepared by the authors (2018).

The network in Figure 8 shows the Giant Component illustrating the Natural Persons (NP) and Legal Entities (LE). The orange nodes are the LE shareholders; the green nodes are the NP, while gray nodes represent the companies. Regarding the totality of nodes of the shareholders, the layout of Figure 8 shows the higher participation of LE shareholders, where about $67.4 \%$ are LE and only $32.6 \%$ are NP.

Communities of the giant component. For a deeper analysis of the giant component, communities (also called subgroups) were formed through the Gephi software and the algorithm of Blondel et al. (2008). As a result, nine communities were generated, with a modularity of 0.8 , that is, an index very close to a high formation of subgroups. Figure 9 shows the giant component and the nine formed communities, differentiated by colors. 
BBR

16

530

Table 2

Centrality Measures

\begin{tabular}{lccccc}
\hline Name & Type & PageRank & Degree & Intermediation & Proximity \\
\hline BNDESPAR & Shareholder & 0.0177 & 31 & 0.5982 & 0.2241 \\
Previ & Shareholder & 0.0087 & 17 & 0.3395 & 0.2022 \\
BlackRock & Shareholder & 0.0073 & 14 & 0.3052 & 0.1927 \\
MYPK3 & Company & 0.0066 & 10 & 0.0247 & 0.1175 \\
MOAR3 & Company & 0.0065 & 10 & 0.0247 & 0.1179 \\
SCAR3 & Company & 0.0065 & 10 & 0.0247 & 0.1345 \\
SULA3 & Company & 0.0063 & 10 & 0.0247 & 0.1622 \\
CATA3 & Company & 0.0062 & 10 & 0.0247 & 0.1374 \\
ROMI3 & Company & 0.0061 & 10 & 0.0247 & 0.1429 \\
RADL3 & Company & 0.0061 & 10 & 0.0382 & 0.1626 \\
\hline
\end{tabular}

Source: Prepared by the authors (2018).

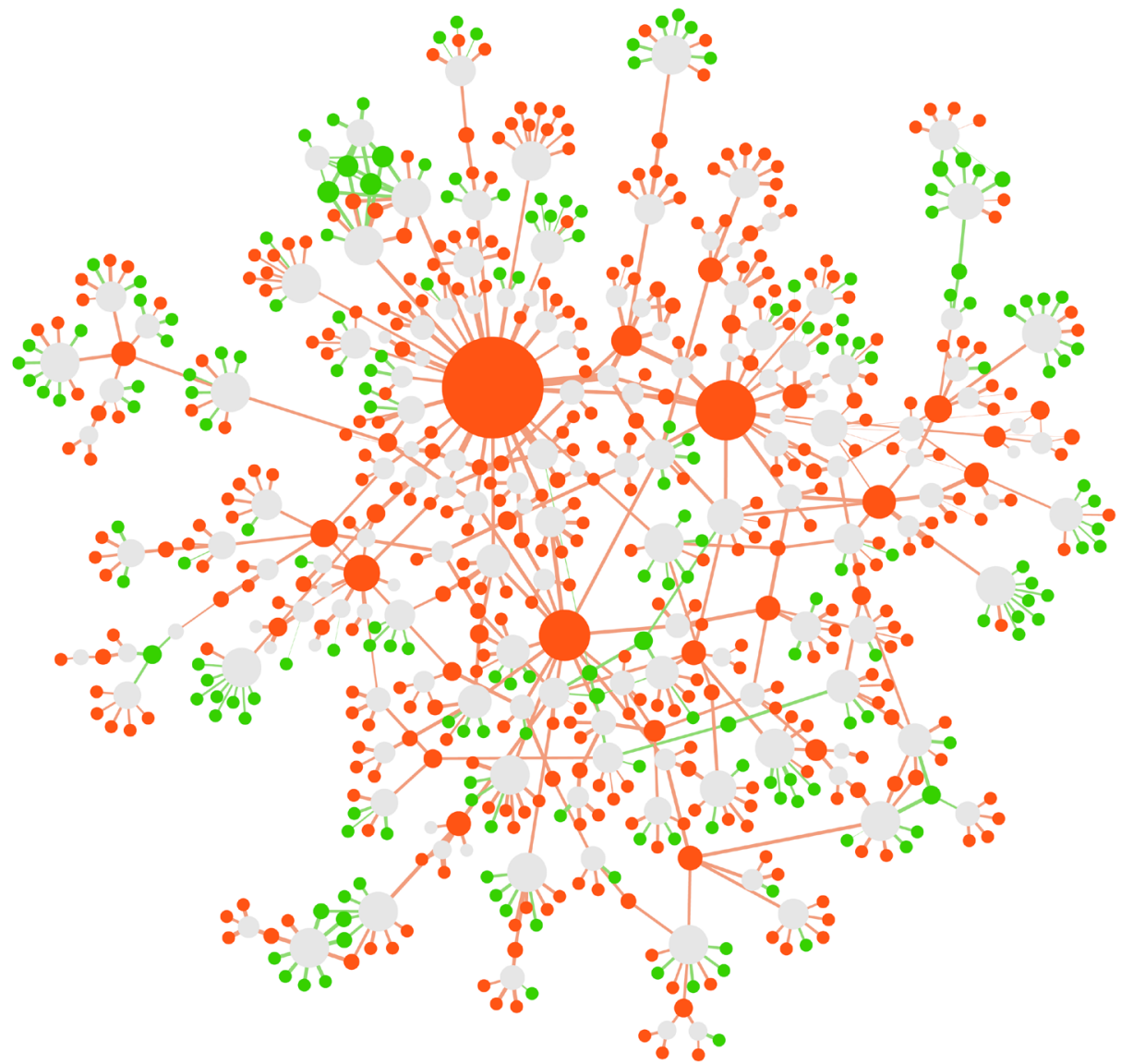

Figure 8. Giant component: LE shareholders (orange), NP (green) and companies (gray). Source: Prepared by the authors using Gephi (2018).

Figure 10 summarizes the community network (aggregating their nodes) in order to highlight the links between them. Each node therein represents a community, and its size was defined according to the number of nodes present in each community. The nomenclature indicates the shareholder with the highest PageRank in the community. 


\subsection{Network of Shareholders}

From the giant component, the nodes representing the companies were omitted, through the

Gephi software plugin called MultiMode Networks Projections, starting from a bipartite network to a simple network. The resulting network is formed by 573 shareholders connected to each

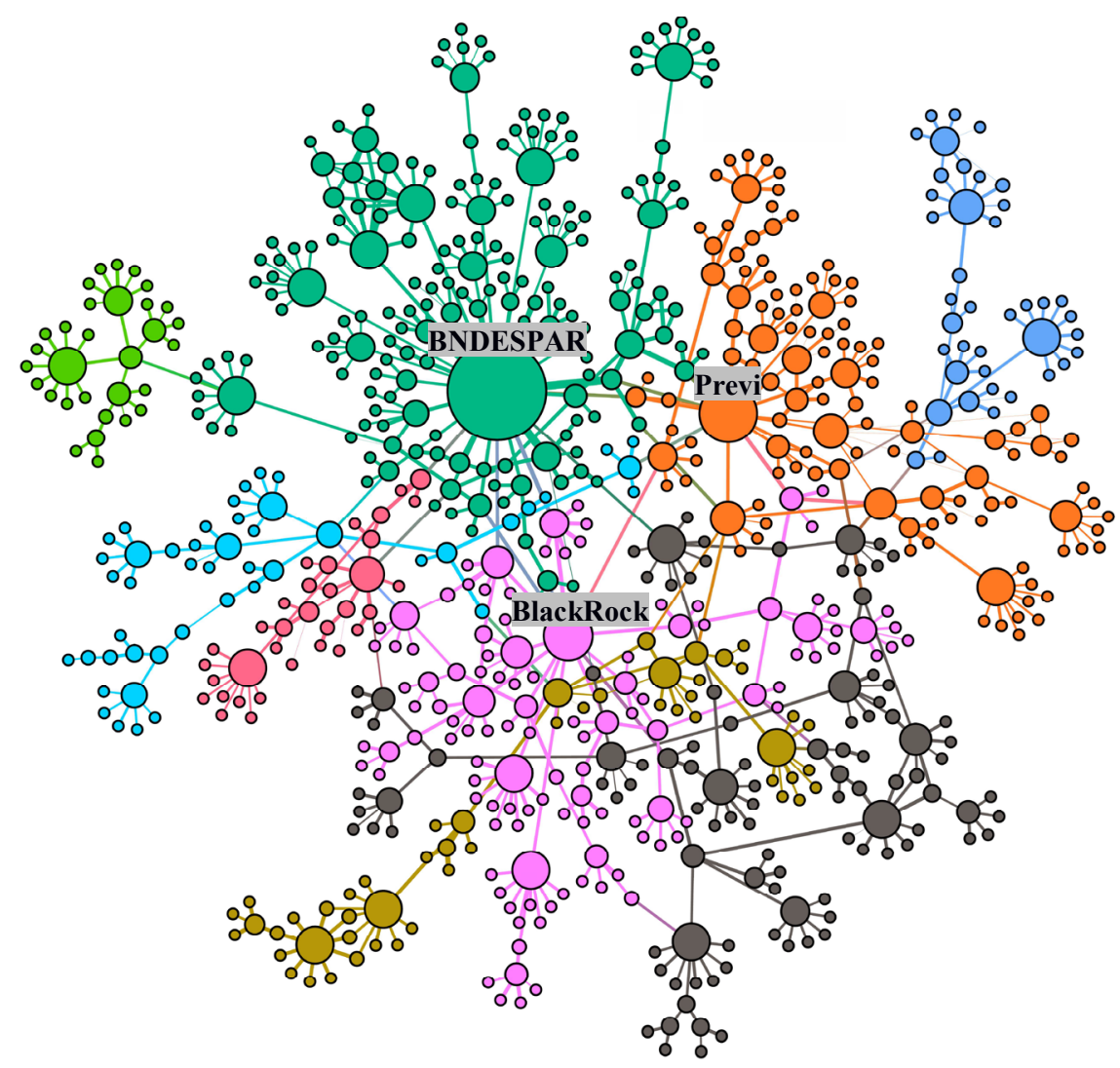

Figure 9. Giant Component Community Network.

Source: Prepared by the authors using Gephi (2018).

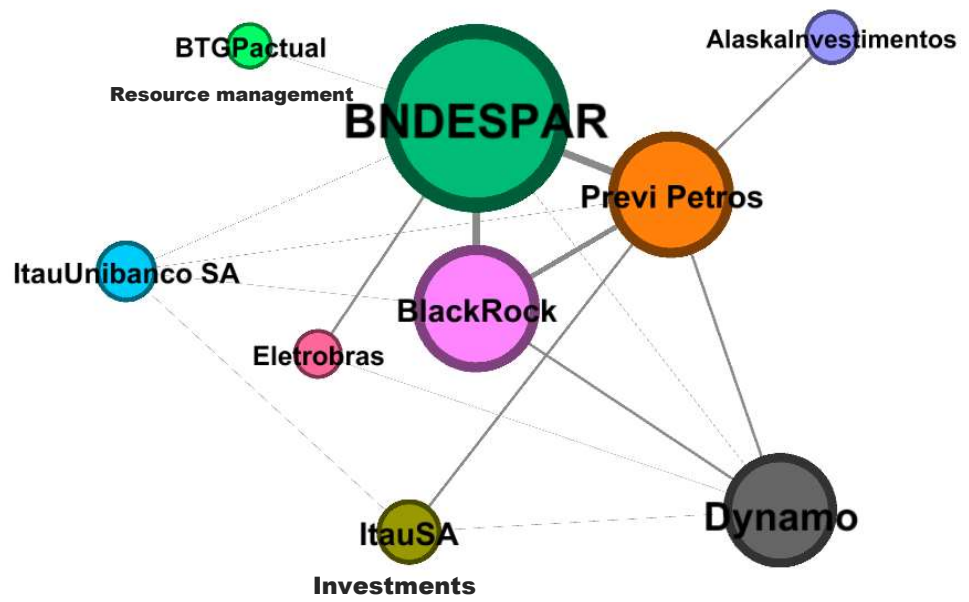

Figure 10. Summary Community Network.

Source: Prepared by the authors using Gephi (2018). 
BBR

16

532

other due to common ownership in the same companies. Table 3 shows the main information regarding the network of shareholders.

In order to identify the profile of shareholders within this network, the nodes of shareholders were allocated according to the following classes: "natural person", "financial and others", "holdings and private equity firms", "proprietary", "funds"," State", "energy sector" and "others". It is important to emphasize that this classification sought to create as the fewest classes as possible, in which all the players could be allocated in order to allow better visualization of the network. Table 4 shows the classes and the corresponding percentage of nodes in each of them.

Aimed at a better view of the network, colors are attributed only to nodes within the five first classes, as they present higher volume of incidence in the network. Figure 11, adapted from Gephi, shows the classes and the corresponding colors of nodes.

Figure 12 shows the colorful network according to the classes created and the main players BNDESPar, BlackRock and Previ located in central positions in the network. It is possible to see the branching of nodes that represent the holdings, the private equity companies, and funds. A highlight should be given to players belonging to the financial sector, that are present in almost the entire network, acting as important intermediaries. The nodes regarding the shareholders that are natural persons are not usually intermediaries among other nodes in the network, being arranged mainly in the extremities. Thus, it can be observed a high relevance of players belonging

Table 3

Information Regarding the Network of Shareholders

\begin{tabular}{lc}
\hline Network & Shareholders \\
\hline Type & Not directed \\
Number of nodes & 573 \\
Number of edges & 2,124 \\
Average degree & 7.41 \\
Connected components & 1 \\
Diameter & 10 \\
Density & 0.013 \\
Average path length & 4.005 \\
\hline
\end{tabular}

Source: Prepared by the authors (2018).

Table 4

Classes of Shareholders and their Corresponding Percentages

\begin{tabular}{lc}
\hline Class & $\%$ of nodes \\
\hline Natural Person (NP) & $31.24 \%$ \\
Financial and others & $17.98 \%$ \\
Holdings and Private Equity Firms (PE) & $15.18 \%$ \\
Proprietary & $12.91 \%$ \\
Funds & $12.74 \%$ \\
Others & $5.93 \%$ \\
Energy sector & $2.79 \%$ \\
State & $1.22 \%$ \\
\hline
\end{tabular}

Source: Prepared by the authors (2018). 
to the financial segment with nodes responsible for connecting other shareholders to the rest of the network.

Table 5 contains the 15 largest shareholders according to PageRank and, in addition to the classes, presents other centrality measures, such as degree, intermediation and proximity. Once 2again, according to information observed in Figure 12, there is a relevant presence of financial class nodes, about $53 \%$ of the 15 nodes with the highest PageRank of the network. Additionally, we have the National Treasury, the central body of the Federal Financial Administration System and the Federal Accounting System; Eletrobras SA, a holding under the control of the Federal Government that operates in the generation, transmission and distribution of electric power; and Elie Horn, a natural person shareholder, of Syrian origin, founder of Cyrela, an important real estate company in Brazil.

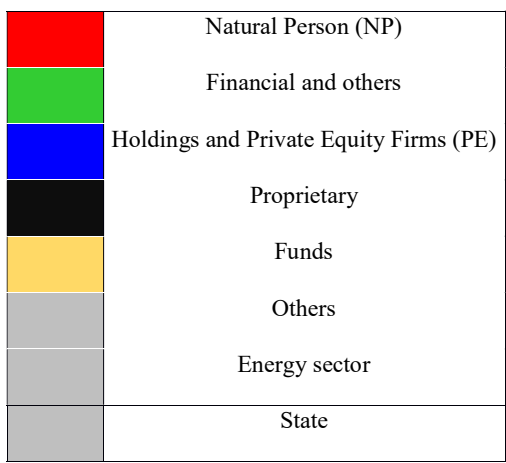

Figure 11. Classes and colors of the network of shareholders.

Source: Prepared by the authors, obtained using Gephi (2018).

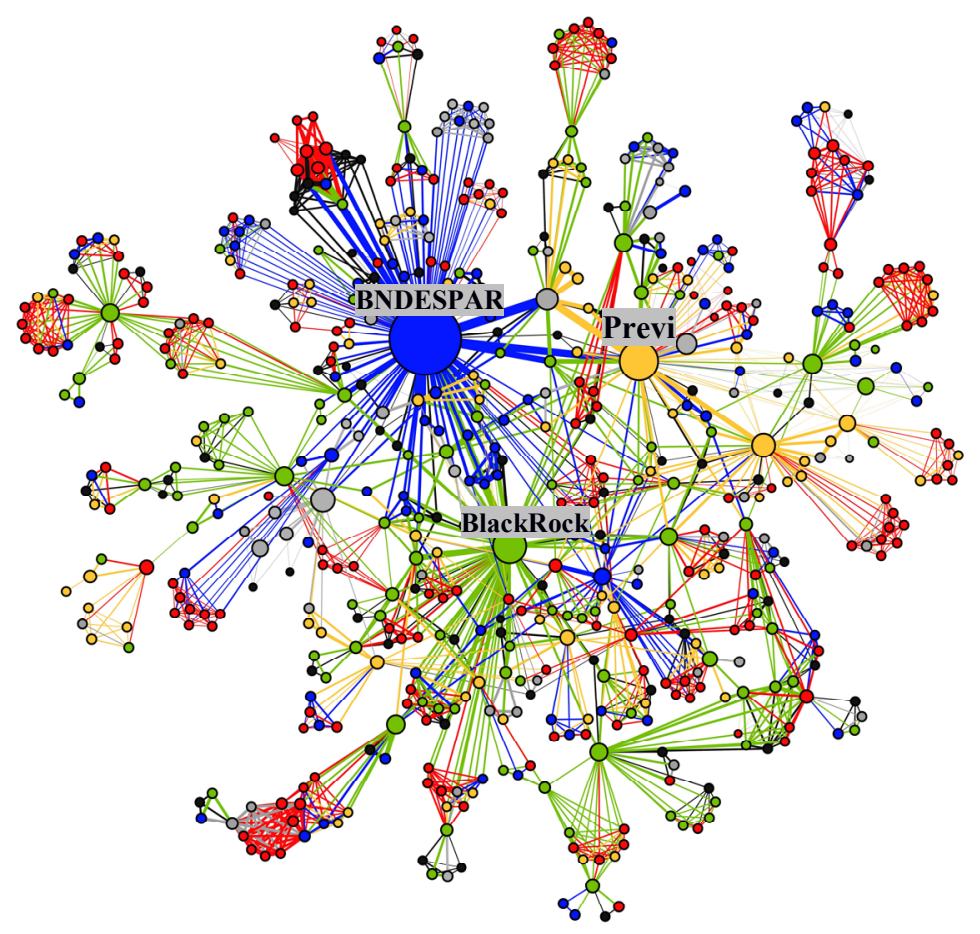

Figure 12. Network of shareholders by class.

Source: Prepared by the authors, obtained using Gephi (2018). 
BBR

16

534

Table 5

Major shareholders of the giant component by PageRank

\begin{tabular}{|c|c|c|c|c|c|}
\hline Player & PageRank & Class & Degree & Intermediation & Proximity \\
\hline BNDESPAR & 0.036076 & Holdings and PE & 130 & 0.564 & 0.431 \\
\hline Blackrock & 0.017448 & $\begin{array}{c}\text { Financial and } \\
\text { others }\end{array}$ & 72 & 0.300 & 0.375 \\
\hline PREVI & 0.016704 & Funds & 59 & 0.295 & 0.389 \\
\hline Petros & 0.009479 & Funds & 41 & 0.085 & 0.323 \\
\hline National Treasury & 0.00813 & State & 19 & 0.071 & 0.343 \\
\hline $\begin{array}{l}\text { BTG Pactual Gestão } \\
\text { de Recursos }\end{array}$ & 0.006801 & $\begin{array}{l}\text { Financial and } \\
\text { others }\end{array}$ & 32 & 0.085 & 0.260 \\
\hline $\begin{array}{l}\text { Dynamo Administração } \\
\text { de Recursos }\end{array}$ & 0.006553 & $\begin{array}{l}\text { Financial and } \\
\text { others }\end{array}$ & 30 & 0.100 & 0.299 \\
\hline Bonsucex Holding & 0.006307 & Holding e EP & 29 & 0.076 & 0.311 \\
\hline Itau Unibanco SA & 0.006202 & $\begin{array}{l}\text { Financial and } \\
\text { others }\end{array}$ & 26 & 0.117 & 0.329 \\
\hline $\begin{array}{l}\text { Standard Life Aberdeen } \\
\text { Plc }\end{array}$ & 0.006047 & $\begin{array}{l}\text { Financial and } \\
\text { others }\end{array}$ & 23 & 0.092 & 0.336 \\
\hline Eletrobras S.A & 0.005897 & Public Utility & 17 & 0.048 & 0.311 \\
\hline Lazard Asset Management & 0.005833 & $\begin{array}{l}\text { Financial and } \\
\text { others }\end{array}$ & 19 & 0.045 & 0.297 \\
\hline Alaska Investimentos & 0.005632 & $\begin{array}{l}\text { Financial and } \\
\text { others }\end{array}$ & 24 & 0.107 & 0.302 \\
\hline $\begin{array}{l}\text { Capital World } \\
\text { Investidores }\end{array}$ & 0.004558 & $\begin{array}{l}\text { Financial and } \\
\text { others }\end{array}$ & 19 & 0.014 & 0.330 \\
\hline Elie Horn & 0.004338 & Pessoa Física & 18 & 0.021 & 0.266 \\
\hline
\end{tabular}

Source: Prepared by the authors (2018).

\section{FINAL CONSIDERATIONS}

The total network obtained is formed by 1,742 nodes, where 367 are companies and 1,375 shareholders, with 1,662 edges. It is possible to observe therein, the presence of 175 connected components, being a giant component, with about $41.7 \%$ of players present in the network. Regarding the giant component, the presence of highly connected hubs and the presence of the three main shareholders thereof are observed: BNDESPar, Previ and BlackRock. Regarding the profile of members of the giant component, about $67 \%$ are legal entities and $33 \%$ are natural persons.

The giant component was divided into nine communities through Gephi software and the algorithm of Blondel et al. (2008), presenting a modularity of 0.8 , value that is very close to an optimal division of communities. Based on the giant component analysis, the shareholder network comprised of the 573 nodes presented low density, high modularity and medium average path length, indicating a tendency to be characterized as a small world network. It was possible to observe the important role of the players of the financial sector, holdings, private equity companies and funds, which were present in almost the entire network, acting as important connectors, while the individual shareholders are mainly arranged in the network periphery, not playing the important role of intermediates. 
The three major shareholders identified in the network are institutional, namely: BNDESPar, Previ and BlackRock, which present the highest centrality measures (PageRank, degree, intermediation and proximity), with highlight to BNDESPar, the most central shareholder of the network. BNDESPar, as a government holding company, indicates relevant government action in the Brazilian capital market, mainly in the development and maintenance of important companies, mitigating the effects of financial capitalism, as well as its social consequences. Thus, the State acts not only in regulating the market, but also as an important shareholder, with BNDESPar acting as the agency representing it in the venture capital industry, operating its strategies and evidencing the high power of government influence in Brazilian capitalism and in the development of important companies.

The initial perspective addressed in this article is believed to contribute to future studies, such as temporal analysis, observing the changes in the network structure over time, as well as the changes in the political, economic and social scenarios. Moreover, it is possible to compare the network structure obtained in this work with the network structure in other countries.

Limitations and / or possibilities for improvements can concentrate on the database by identifying nodes that represent the same player, but with different names/CNPJs, and transforming them into a single node, in order to identify different links and, perhaps, new patterns in the network. It is an exploratory thorough work, but of high relevance.

\section{REFERENCES}

Araújo, R. A. M.; Santos, L. M. S. (2016, nov.). Determinantes do grau de concentração acionária no Brasil: um estudo com as empresas listadas no nível tradicional da BM\&FBOVESPA. XXIII Congresso Brasileiro de Custos, Porto de Galinhas.

Barabási, A. L. (2016). Network science. Cambridge: University Printing House.

Baran, P. (1964). On distributed communications: introduction to distributed communications networks. Califórnia: The Rand.

Berle, A.A., \& Means, G.C. (1932). The modern corporation and private property. New York: Macmillan.

Blondel, V. D., Guillaume, J. L., Lambiotte, R., \& Lefebvre, E. (2008). Fast unfolding of communities in large networks. Journal of Statistical Mechanics: Theory and Experiment, 1, 1-12. doi: 10.1088/1742-5468/2008/10/P10008

BM\&FBOVESPA. (2017, 13 mar.). BM\&FBOVESPA institucional. Retrieved from: http://www. bmfbovespa.com.br/pt_br/institucional/sobre-a-bm-fbovespa/quem-somos/

Caixe, D. F., \& Krauter, E. (2013). The influence of the ownership and control structure on corporate Market value in Brazil. Revista de Contabilidade e Finanças, 24(62), 142-153. Retrieved from: http://www.scielo.br/scielo.php?script=sci_abstract\&pid=S1519-70772013000200005\&lng $=\mathrm{pt} \& \mathrm{nrm}=\mathrm{iso} \& \mathrm{t} \operatorname{lng}=\mathrm{en}$

Carneiro, M. G. (2017). Redes complexas para classificação de dados via conformidade de padrão, caracterização de importância e otimização estrutural (Tese de doutorado). ICMC USP, São Carlos.

Claessens, S., Djankov, S., Fan, J. P. H., \& Lang, L. H. P. (2002). Disentangling the incentive and entrenchment effects of large shareholdings. The Journal of Finance, 57(6), 2741-2771. doi: 10.1111/1540-6261.00511

CVM. (2013). Mercado de Valores Mobiliários Brasileiro. Rio de Janeiro: CVM. 
BBR

16

536

Easley, D., \& Kleinberg, J. (2010). Networks, Crowds and Markets: Reasoning about a Highly Connected World. Nova Iorque: Cambridge University Press.

Fortuna, E. (2008). Mercado Financeiro: produtos e serviços (17a. ed.). Rio de Janeiro: Qualitymark.

Gephi. (2017, 24 mar.). Software Gephi. Retrieved from: https://www.gephi.org

Gitman, L.J. (2010). Princípios de Administração Financeira (12a. ed.). São Paulo: Pearson.

Glattfelder, J.B. (2013). Decoding complexity: uncovering patterns in economic networks. Springer.

Jensen, M. C., \& Meckling, W. H. (1976). Theory of the firm: managerial behavior, agency costs and ownership structure. Journal of Finance Economics, 3(4), 305-360. doi: 10.1016/0304-405X(76)90026-X

La Porta, R., Silanes, F. L., \& Shleifer, A. (1999). Corporate Ownership Around the World. The Journal of Finance, 54(2), 471-517. doi: 10.1111/0022-1082.00115

Lazzarini, S. G. (2008). Empresas em rede. São Paulo: Cengage Learning.

Leal, R. P. C., Silva, A. L. C., Valadares, S. M. (2002). Estrutura de controle das companhias brasileiras de capital aberto. Revista de Administração Contemporânea, 6(1), 7-18. doi: 10.1590/ S1415-65552002000100002.

Luce, R.D., Perry, A.D. (1949). A method of matrix analysis of group structure. Psychometrika, 14(1), 95-116. doi: 10.1007/BF02289146

Newman, M.E.J. (2006). Modularity and community structure in networks. Proceedings of the National Academy of Sciences, 103(23), 8577-8582. doi: 10.1073/pnas.0601602103

Newman, M.E.J. (2010). Networks: an introduction. Nova Iorque: Oxford University Press.

Ribeiro, E.M.S. (2014). Árvore geradora mínima aplicada ao estudo da interligação administrativa em empresas listadas na BM\&FBOVESPA (Tese de livre docência). FEARP USP, Ribeirão Preto.

Scott, J. (2017). Social Network Analysis (2a. ed.). Londres: SAGE Publications.

Segatto-Mendes, A.P. (2001). Teoria de agência aplicada à análise de relaçóes entre os participantes dos processos de cooperação tecnológica universidade-empresa. (Tese de doutorado). Faculdade de Economia Administração e Contabilidade da Universidade de São Paulo. São Paulo.

Siffert Filho, N. (1998). Governança corporativa: padrões internacionais e evidências empíricas no brasil nos anos 90. Revista BNDES, 5(9). Retrieved from: http://web.bndes.gov.br/bib/ jspui/handle/1408/11394

Silveira, A. M. (2015). Governança corporativa no Brasil e no mundo: teoria e prática. (2a. ed). Rio de Janeiro: Elsevier.

Ravasz, E., Somera, A. L., Mongru, D. A., Oltvai, Z. N., \& Barabási, A.L. (2002) Hierarchical organization of modularity in metabolic networks. Science, 297(5586), 1551-1555. doi: 10.1126/science. 1073374

Vitali, S., Glattfelder, J. B., \& Battiston, S. (2011). The Network of Global Corporate Control. PLoS ONE, 6(10), 1-6. doi: 10.1371/journal.pone.0025995

\section{ACKNOWLEDGMENT}

The authors would like to thank the editors and the anonymous reviewers for their comments and suggestions. EMS Ribeiro would like to thank Fundação para Pesquisa e Desenvolvimento da Administração, Contabilidade e Economia (FUNDACE), Brazil, for the financial support for this research under the grant $n^{\circ} 0111 \_1 / 2015$. 